\title{
OCCUPATIONAL EXPOSURE TO BIOLOGICAL AGENTS IN POLISH PARAMEDICS: A NARRATIVE REVIEW
}

\author{
Agnieszka Gonczaryk ${ }^{1} \odot$, Jaroslaw Chmielewski ${ }^{2} \oplus$, Malgorzata Dziechciaz ${ }^{3} \odot$, \\ Izabela Wroblewska ${ }^{4} \oplus$, Jarogniew J. Luszczki ${ }^{5} \odot$ \\ 'Department of Health and Social Policy, Marshal's Office in Warsaw, Poland \\ ${ }^{2}$ College of Rehabilitation in Warsaw, Poland \\ ${ }^{3}$ Health Care Institute, State School of Higher Vocational and Economic Education, Jaroslaw, Poland \\ ${ }^{4}$ Department of Internal Nursing, Department of Nursing and Midwifery, Faculty of Health Sciences, Wroclaw Medical University, Wroclaw, Poland \\ ${ }^{5}$ Institute of Rural Health in Lublin, Poland
}

\begin{abstract}
INTRODUCTION: Research into occupational exposure to biological pathogens during medical personnel work is to a small degree concerned with paramedics. Coming in contact with biological pathogens, like HIV, HCV and HBV viruses, tubercle bacilli, or recently the SARS-CoV-2 virus in the workplace is a contamination risk. This study aims to analyze the occupational exposure of paramedics to biological pathogens at work, the possibilities of paramedics developing contagious diseases as occupational illnesses, and the prophylaxis this involves.
\end{abstract}

MATERIAL AND METHODS: The publication was prepared on the basis of a literature review of works available in the PubMed, SCOPUS, and Google Scholar databases, and on websites of institutions functioning in the area of public health.

BRIEF DESCRIPTION OF THE STATE OF KNOWLEDGE: In Poland, in 2020, there were 1255625 cases of SARSCoV-2 registered, 3020 of which are cases found in paramedics, and 12524 cases of Lyme borreliosis, $990 \mathrm{HBV}$ cases, 942 HCV cases, 934 HIV cases. In 2020, there were 1861 occupational diseases, 504 of which were contagious or parasitic. Approximately 37000 needlesticks are estimated to happen every year in medical facilities. $40 \%$ to $80 \%$ of the people who got injuries or cut in the workplace did not report the incident.

CONCLUSIONS: There is a need to implement prophylactic and preventative measures to prevent occupational needlestick injuries and blood-borne infections amongst paramedics. Paramedics show insufficient knowledge of their ability to apply for an occupational disease diagnosis caused by exposure to biological pathogens present in the work environment.

KEY WORDS: paramedics, biological factors, workplace, occupational exposure, prophylaxis of occupational infections, biological hazards, personal protective equipment, occupational disease.

Disaster Emerg Med J 2021; 6(4): 194-203

\section{INTRODUCTION}

The quality of the environment is a significant factor of individual and public health. It is assumed that environmental health is determined by bi- ological, chemical, physical, and social factors. It involves both theoretical and practical concepts as far as the evaluation, elimination, and prevention are concerned when it comes to the presence

ADDRESS FOR CORRESPONDENCE:

Jarosław Chmielewski, College of Rehabilitation in Warsaw, Warsaw, Poland

e-mail: j.chmielewski@ios.gov.pl

This article is available in open access under Creative Common Attribution-Non-Commercial-No Derivatives 4.0 International (CC BY-NC-ND 4.0) license, allowing to download articles and share them with others as long as they credit the authors and the publisher, but without permission to change them in any way or use them commercially. 
of such factors, which can negatively affect the health of the current and subsequent generations, in the environment. Environmental health is entirely consistent with the broad understanding of worker healthcare. The health of workers is directed at the measures related to the promotion and maintenance of the highest level of physical and psychological fitness, as well as the well-being of employees, which are interested in technical, medical, and organizational means of reducing harmful health effects resulting from the work process [1].

Paramedics carry out their professional tasks in extremely difficult work environment conditions. The work they do in healthcare units is considered one of the occupations where healthcare workers (HCW) are exposed to illnesses caused by biological pathogens. They are at a greater risk of falling ill in comparison with the general society, especially during a contagious disease pandemic.

Microorganisms, internal parasites, acellular units capable of replication or transferring genetic material, including genetically modified cell cultures, which may be the cause of infection, allergy, or poisoning [2].

In the most general sense, the work environment is understood as a collection of spatially or organizationally defined workplaces, shaped by the conditions of the material environment with particular biological pathogens, where the process of work takes place and workers carry out professional activities [3].

Studies suggest a significant effect of the work environment on the individual health condition of a worker $[3,4-7]$. In the process of caring for the health of workers, it is of importance to properly identify factors that are potentially detrimental to the health and are a result of the work environ- ment as well as appropriately choosing preventative measures, including personal protective equipment, depending on the identified threat or an established scale of health hazard $[1,8,9]$.

The risk of biological pathogen infection incidence may significantly affect the health condition. Coming in contact with dangerous biological pathogens in the workplace, such as hepatitis B virus (HBV), hepatitis type $C(\mathrm{HCV})$, human immunodeficiency virus (HIV), tubercle bacilli, or contemporarily, severe acute respiratory syndrome coronavirus 2 (SARS-CoV-2) causes there to be a real danger of an individual HCW's health condition deteriorating, resulting in, e.g., infection, mental health deterioration, or even death [9-12].

Table 1 shows the employment status of HCW and the exposure to identified biological pathogen factors present in the work environment, relative to the general employed population in the year 2020 [13].

According to the data contained in the epidemiological reports (EPIMELD) of the National Institute of Public Health $\mathrm{NIH}$ - National Research Institute (NIZP PZH-PIB), in 2020 in Poland, there have been 1255625 cases of SARS-CoV-2 infection registered, 12524 cases of Lyme borreliosis, 990 cases of HBV, 942 cases of HCV, 934 cases of HIV, 265 cases of viral meningitis, 158 cases of tick-borne encephalitis (TBE) infection and 109 cases of hepatitis $A$ virus infections (HAV) [14].

Table 2 shows the SARS-CoV-2 virus infection rated for HCW in 2020 [11].

According to the data of the Chief Sanitary Inspectorate (CSI) in Poland, in 2020, there have been 1861 occupational diseases diagnosed (in 2019 - 2 059), 504 of which are cases of contagious or parasitic diseases (in comparison with 2019 - 705 cases) [15].

\begin{tabular}{|c|c|c|c|c|c|c|}
\hline \multicolumn{7}{|c|}{ Exposure to biological risk factors by sections and divisions in 2020} \\
\hline \multirow{3}{*}{\multicolumn{2}{|c|}{$\begin{array}{c}\text { SPECIFICATION } \\
\mathrm{a}-\text { total } \\
\mathrm{b}-\text { per } 1000 \text { employees in units covered } \\
\text { by the survey }\end{array}$}} & \multicolumn{4}{|c|}{ Employees exposed to risk factors which were, over the year } & \multirow{4}{*}{\begin{tabular}{|c|}
$\begin{array}{c}\text { As of } 31 \\
\text { December }\end{array}$ \\
19752 \\
\end{tabular}} \\
\hline & & \multicolumn{3}{|c|}{ Eliminated or reduced } & \multirow{3}{*}{\begin{tabular}{|l}
$\begin{array}{c}\text { Identified } \\
\text { (including newly } \\
\text { arisen risks) }\end{array}$ \\
11871 \\
\end{tabular}} & \\
\hline & & Total & $\begin{array}{l}\text { Eliminated or reduced to } \\
\text { the standard level }\end{array}$ & Reduced & & \\
\hline TOTAL & a & 13705 & 3890 & 9815 & & \\
\hline & $b$ & 2.3 & 0.6 & 1.6 & 2.0 & 3.3 \\
\hline \multirow[t]{2}{*}{ Only division Human health activities } & a & 7396 & 1487 & 5909 & 8191 & 12760 \\
\hline & $b$ & 13.6 & 2.7 & 10.9 & 15.1 & 23.5 \\
\hline
\end{tabular}


Table 2. People working in medicine who have been diagnosed with a SARS-CoV-2 virus infection, including incidences of illness and death due to COVID-19 (modified) [11]

\begin{tabular}{|l|l|l|}
\hline \multicolumn{1}{|c|}{ Medical profession } & \multicolumn{1}{|c|}{ Number of confirmed COVID-19 cases } & \multicolumn{1}{|c|}{$\begin{array}{c}\text { humber of deaths from COVID-19 among } \\
\text { hospitalized patients }\end{array}$} \\
\hline Doctor & 20476 & 66 \\
\hline Dentist & 1884 & 10 \\
\hline Nurse & 50990 & 51 \\
\hline Midwife & 4764 & 4 \\
\hline Paramedic & 3020 & 5 \\
\hline Pharmacist & 2106 & 5 \\
\hline Laboratory diagnostician & 1555 & 0 \\
\hline Feldsher & 26 & 4 \\
\hline Total & 84821 & 145 \\
\hline
\end{tabular}

Table 3. Shortcomings in the area of health and safety at work detected during inspections of medical entities in the years 2018-2020 - the percentage of the entities where shortcomings were found (modified) [16]

\begin{tabular}{|l|l|l|l|}
\hline \multicolumn{1}{|c|}{ Specification } & 2018 & 2019 & 2020 \\
\hline Lack of a documented evaluation of the occupational risk at all of the work posts & 42 & 37 & 46 \\
\hline Shortcomings related to equipment with a work uniform and work shoes & 35 & 42 & 41 \\
\hline Improper identification of the risks related to the carried-out work & 41 & 45 & 33 \\
\hline Shortcomings related to the initial training & 39 & 25 & 24 \\
\hline
\end{tabular}

The clear fall in the number of reported contagious disease cases is largely a result of the declaration of a pandemic, in relation to the SARS-CoV-2 virus infections, as well as the implementation of epidemiological safety rules, which consist of wearing protective face masks, more frequent washing and disinfecting hands, maintaining social distancing. It has to be noted, however, that the data largely omit cases of acute contagious disease of the respiratory system caused by the SARS-CoV-2 (COVID-19) virus infection, which is a contagious disease classified as an occupational disease amongst HCW. The above is most likely the result of underreporting by HCWs [11].

The data of the National Labor Inspectorate (PIP) confirm just how important the issues of health and safety at work, including the correct identification of risk factors, and consequently the effect of the exposure to harmful factors of the work environment on the health of HCW, are in the area of worker healthcare. In 2020, PIP investigated 46 medical entities employing 16.3 thousand people. Compliance with health and safety at work regulations related to preparing for work, exposure to harmful and cumbersome agent activity, personal protection equipment, work uniforms and shoes, the supervision and con- trol over the state of health and safety at work, were all under investigation. In PIP's opinion, the lack of knowledge of employers and managers in charge of employees is a frequent cause of shortcomings in the area of health and safety at work. It causes failures to occur during the evaluation of occupational risk, including the identification of threats present in the work environment. The identified shortcomings involved, e.g., a lack of descriptions of evaluated workspaces specifying what tools and materials were in use, as well as the absence of the identification of all the threats, including those caused by biological pathogens, such as SARS-CoV-2, present in the work environment. HCW was noted to not be properly equipped with work uniforms and shoes, as well as personal protection equipment, in $41 \%$ and $11 \%$ of the investigated entities respectively. There have been cases of HCW using their own clothes and shoes when carrying out work where exposure to harmful biological pathogens takes place [16].

Table 3 shows the shortcomings in the area of health and safety at work detected during inspections of medical entities in the years 2018-2020 [16].

The proper protection of the professional group that paramedics constitute, in both the context of 
individual and population health, against the negative effects of biological factor activity on the body is an important issue. An indication of that could be, for example, the fact that, as demonstrated by the Supreme Audit Office (NIK) in their post-control address, in February of 2020, disposable Individual Personal Protection Packages, which were in possession of the Cracow Emergency Medical Services (KPR), were enough to protect just $50 \%$ of the paramedics. In the period between 01.01.2018 and 30.05.2020, KPR had one disposable transport isolator, the G07 model, to transport people who were suspected of suffering from a particularly dangerous and highly contagious disease. Another indication of insufficient protection of paramedics against the possibility of SARS-CoV-2 virus infection during transport is the fact that in the initial stages of the pandemic, KPR had transported 457 people suspected of COVID-19 by the $5^{\text {th }}$ of May 2020 . Before the outbreak of the pandemic caused by the SARS-CoV-2 virus, KPR employees had not partaken in practical exercises on how to proceed in case of a particularly dangerous and highly contagious disease threat [17].

According to the data from NIK for Poland in 2019, there were 1577 Emergency Response Teams (369 of which specialized, and 1208 general) functioning under the Emergency Medical Service System [18], meanwhile according to the data of the e-Health Centre, there were 14473 paramedics working in healthcare facilities in 2019 [19].

The emergence of new species of microorganisms, as well as the development of research techniques, causes new biological factors, which are occupational hazards, to be detected in the work environment. Important issues surrounding biological factors of occupational hazards for paramedics include, e.g., blood-borne viruses; new species of viruses (SARS-CoV-2), prions and bacteria, germs carried by ticks (in cases of carrying out work tasks in wooded areas); allergenic and immunotoxic factors of microbe, plant, and animal origin present in organic dust [20-24].

The small number of paramedics determines the number of studies and publications on the subject of occupational exposure to biological pathogens present during work and the related health effects. The knowledge of paramedics, their personal stance in the face of a possibility of contracting contagious diseases, as well as the environment they work in, may become an obstacle in the prevention of ad- verse health effects from occurring. These barriers increase the risk of susceptibility to contagious diseases.

Prophylactic measures aimed at the minimalization of the risk of infection amongst paramedics should include information about biological factors (pathogens) that may possibly be encountered in the work environment, infection spreading pathways, and guidelines regarding the protection against any such threats. We distinguish three pathways via which infections spread: direct (e.g., direct contact with a patient during an examination, direct contact with blood and body fluids), indirect (e.g., through air and droplets, through air and dust, objects of everyday use) and mixed [1, 3].

\section{BLOOD-BORNE ETIOLOGICAL FACTORS}

The possibility of paramedics coming in contact with human blood is an important issue in the area of occupational exposure to biological factors in this particular group of healthcare workers. As far as biological hazards in the work environment are concerned, HIV, HBV, and HVC are of the most significant importance due to the rate of incidence and their effects on health.

Available information and data regarding occupational exposure to blood amongst paramedics give basis to the claim that exposure to blood-borne pathogens is a genuine risk in this professional group. The percentages of paramedics who have been exposed to blood in the year leading up to the study vary greatly between countries, fluctuating between $22 \%$ in the USA to $63 \%$ in Thailand, meanwhile in Poland results oscillate between 14 and 78\% [25-28].

Viruses of human origin that are transported by blood or other body fluids are the most frequent cause of occupational diseases amongst HCW. Due to the nature of the tasks they have to carry out at work, they are naturally exposed to blood and body fluids in the workplace. A lack of due caution while carrying out work tasks, needlesticks, cuts, lack of personal protection equipment, are the factors that make infections with blood-borne pathogens, including HIV, HBV, HCV, or the Ebola virus (EBOV), plausible and capable of taking place in the work process [29-32]. It is estimated that the risk of contracting HBV amongst HCW is approximately 10 times higher than for the general population [33]. 
One study, the aim of which was to estimate incidence rates of occupational blood exposure by route of exposure (needlesticks; cuts from sharp objects; mucous membrane exposures to the eyes, nose, or mouth; bites; and blood contact with nonintact skin) in the target population of active paramedics in the USA, including the state of California, studied 2664 people. The study showed that the proportions of paramedics who reported exposure in the previous year were $21.6 \%$ (95\% confidence interval $[\mathrm{Cl}], 17.8-25.3)$ for the national sample and $14.8 \%$ $(95 \% \mathrm{Cl}, 12.2-17.4)$ for California. The overall incidence rate was 6.0/10 000 calls $(95 \% \mathrm{Cl}, 3.9-8.1)$. These rates represent more than 49000 total exposures and more than 10000 needlesticks per year among paramedics in the United States. Rates for mucocutaneous exposures and needlesticks were similar (w1.2/10 000 calls). Rates for California were one-third to one-half the national rates. Sensitivity analysis showed that potential response bias would have little impact on the policy and intervention implications of the findings [29].

Research into the occupational risk towards blood-borne infections among 161 members of ambulance personnel in a provincial hospital network in Thailand showed that $82 \%$ of the personnel came in contact with jaundice patients in the past, $95 \%$ of the personnel came in contact with acquired immunodeficiency syndrome (AIDS) patients in the past. The study also showed that $63.4 \%$ of the personnel came in contact with a patient's blood through injuries; 64.7 had a needlestick injury, and 24,5\% got cuts from sharp objects [30].

Research carried out on a group of 220 paramedics employed in Emergency Departments and medical rescue teams showed that as many as $80 \%$ of the surveyed people reported frequent contact with patients' blood [31].

A study carried out amongst 145 chosen paramedics employed in different healthcare facilities across Poland intending to identify the rate of incidence of coming in contact with blood and other body fluids, showed that $78 \%$ of paramedics had this kind of contact a couple of times a week, with $41.4 \%$ of the paramedics had this kind of contact more than ten times a day [32].

The results of the research, in which 215 paramedics took part, showed that $57.7 \%$ of the surveyed stated that in the period of the last twelve months before the study took place, they came in contact with potentially contagious material via unharmed skin at least a few times, $22.3 \%$ via mucous membranes, over $16 \%$ a couple of times a year via damaged skin, and $3.7 \%$ were exposed to infection several times during that period as a result of a deep cut. As part of the study, paramedics pointed out that the cause of the cuts was most often the fact that they were in a hurry, the patient's unexpected behavior, insufficient concentration, a stressful situation requiring urgent intervention, an overload of duties [34].

Research shows that in the years 2005-2010, the emergency medical services in Wrocław recorded 49 incidences of dirty needlestick injuries involving paramedics. The circumstances of such events were usually related to the necessity of injecting an anxious patient in a hurry or under bad light [35].

HIV is also a real threat to paramedic health in cases of exposure to blood [36].

The results of the studies show that the risk of seroconversion after percutaneous exposure to infected blood is approximately $0.1-0.3 \%$ for HIV, $2 \%$ for HCV, and $6-60 \%$ for HBV [37].

Table 4, illustrating the number of HBV, HCV, AIDS cases, and HIV infections in Poland in the years 2011-2020, shows just how significant of an occupational exposure factor contaminated blood may be for paramedics [14].

Approximately 37000 needlestick injuries are estimated to take place every year in medical facilities across Poland. Studies show that $40-80 \%$ of the people who suffered from needlesticks or cuts in the workplace did not report the incident $[39,40]$.

\section{ETHOLOGICAL FACTORS TRANSPORTED IN THE DROPLET AND AIR PATHWAYS}

Currently, there is a lack of complete quantitative data on the subject of occupational exposition to biological factors transported in the droplet and air pathway for paramedics. However, literature data related to the incidence of biological factors capable of spreading in such a manner in the environment give basis to the claim that the susceptibility of paramedics to getting infected with them is significant enough not to be neglected while creating safe working conditions. As far as biological hazards in the work environment are concerned, bioaerosols, nowadays the SARS-CoV-2 virus, and tubercle bacilli, are of the greatest importance due to their rate of incidence and health consequences [11, 41].

Tubercle bacilli (Mycobacterium tuberculosis) is a biological factor that has also qualified to haz- 


\begin{tabular}{|c|c|c|c|c|}
\hline \multirow{2}{*}{ Year/number of cases } & \multicolumn{4}{|c|}{ Disease } \\
\hline & HBV & $\mathrm{HCV}$ & AIDS & HIV \\
\hline 2011 & 1583 & 2189 & 241 & 1188 \\
\hline 2012 & 1583 & 2265 & 190 & 1135 \\
\hline 2013 & 1541 & 2644 & 191 & 1159 \\
\hline 2014 & 2763 & 3551 & 151 & 1110 \\
\hline 2015 & 3518 & 4285 & 134 & 1295 \\
\hline 2016 & 3806 & 4261 & 119 & 1387 \\
\hline 2017 & 3363 & 4010 & 117 & 1463 \\
\hline 2018 & 3202 & 3441 & 121 & 1304 \\
\hline 2019 & 2860 & 3341 & 123 & 1751 \\
\hline 2020 & 990 & 942 & 43 & 934 \\
\hline
\end{tabular}

Own work

ard group 3 [2]. The source of infection is an active and non-treated patient, bacteria are transported through droplets and the infection gateways are the respiratory tracts. Incidental infection via an implant pathway, through the skin or mucous membranes, is also possible [42].

Meningococcal infection is caused by bacteria - meningitis diplococci, also referred to as meningococci (Neisseria meningitidis). Meningococci are present in the oronasal cavity of healthy people (so-called carriers), without causing any ailments or symptoms. Infection takes place as a result of a vulnerable person coming in contact with an asymptomatic carrier or a sick person. The transport of meningococci takes place via droplets (while coughing or sneezing). Meningococci are the most frequent cause of meningitis or sepsis (septicemia), which together are referred to as the meningococcal invasive disease. They can also cause, albeit much more rarely, pneumonia, otitis media, pericarditis, endocarditis, arthritis, and other inflammations. Meningococcal invasive disease is a direct threat to one's health and life [43].

SARS Coronavirus Infection, a severe contagious disease characterized by a fever above $38^{\circ} \mathrm{C}$ and respiratory system symptoms, which may lead to acute respiratory failure and death. The source of infection is other sick people. The primary pathway of severe acute respiratory syndrome's (SARS) spread is the droplet pathway - via droplets secreted by the respiratory tracts in the process of coughing or sneezing at a distance of approximately 1 meter. In some rare cases of particularly contagious patients, the infection may spread in the air at greater distances of as much as a few meters. Infection may take place when respiratory tract secretions of an infected person are transported onto the mucus of a healthy person via hands or objects $[44,45]$.

MERS-CoV Infection, a severe contagious disease caused by the MERS-CoV virus, is characterized by a fever above $38^{\circ} \mathrm{C}$, coughing, and other respiratory system symptoms, such as shortness of breath, dyspnea. Death occurs in over $50 \%$ of the patients hospitalized due to MERS-CoV infection. During a pandemic, sick people may be the source of infection. The pathways of spread for the virus have not been identified as of yet. There is data confirming that the germ can be spread via close contact (possibly through droplets and direct contact). The gateway of infection has not been identified. These may possibly include, e.g., oral mucosa and the respiratory system epithelium [44].

SARS-CoV-2 (Severe Acute Respiratory Syndrome coronavirus 2) Infection, is a highly contagious and pathogenic virus causing a severe respiratory system disease called COVID-19. Bioinformatic analyses showed that SARS-CoV-2 had characteristics typical of the family. It belongs to the betacoronavirus $2 \mathrm{~B}$ lineage. SARS-CoV-2 is transmitted via fomites and droplets during close unprotected contact between the infected and uninfected. The main source of infection is symptomatic and asymptomatic patients. The virus may also spread via indirect contact. Droplets containing the virus contaminate the hands, subsequently people touch the mucous tissue of the mouth, nose, and eyes, causing in- 


\begin{tabular}{|c|c|c|c|}
\hline Biological pathogen agent & Method of spread & Effect on people & Prophylaxis \\
\hline Adenoviruses (Adenoviridae) & $\begin{array}{l}\text { Droplet or airborne; } \\
\text { direct }\end{array}$ & Contagious - adenovirus fevers & PPE \\
\hline Coronaviruses (Coronaviridae) & Droplet or airborne & $\begin{array}{l}\text { Contagious - mild upper respiratory tract } \\
\text { diseases }\end{array}$ & PPE \\
\hline $\begin{array}{l}\text { Human B-lymphotropic virus } \\
\text { (HBLV-HHV-6) (Herpesviridae) }\end{array}$ & Direct & Contagious - rash, kidney transplant rejection & $\begin{array}{l}\text { PPE, disinfection, } \\
\text { sterilization }\end{array}$ \\
\hline Echovirus (Picornaviridae) & $\begin{array}{l}\text { Droplet or airborne; } \\
\text { direct }\end{array}$ & $\begin{array}{l}\text { Contagious - respiratory system inflammation, } \\
\text { fever, encephalitis and meningitis, paralysis, } \\
\text { hepatitis, enteritis, dermatitis and rash, } \\
\text { conjunctivitis, diarrhea, myocarditis, and } \\
\text { pericarditis }\end{array}$ & $\begin{array}{l}\text { PPE, disinfection, } \\
\text { sterilization }\end{array}$ \\
\hline $\begin{array}{l}\text { Bacteria (obligatory anaerobic } \\
\text { Gram-negative rods) } \\
\text { Haemophilus influenzae/ } \\
\text { influenza rods }\end{array}$ & $\begin{array}{l}\text { Cirect, } \\
\text { droplet or airborne }\end{array}$ & $\begin{array}{l}\text { Contagious - respiratory system inflammation, } \\
\text { sinusitis, otitis, epiglottitis, meningitis, cellulitis }\end{array}$ & $\begin{array}{l}\text { PPE, preventative } \\
\text { vaccinations } \\
\text { disinfection, } \\
\text { sterilization }\end{array}$ \\
\hline $\begin{array}{l}\text { Bacteria (Rickettsia) Anaplasma } \\
\text { phagocytophilum (synonym: } \\
\text { Ehrlichia phagocytophila) }\end{array}$ & Tick bite & $\begin{array}{l}\text { Contagious (zoonosis) - fever, anaplasmosis } \\
\text { (ehrlichiosis) granulocytic }\end{array}$ & $\begin{array}{l}\text { PPE, quick removal } \\
\text { of the attached ticks, } \\
\text { repellents, disinfection }\end{array}$ \\
\hline
\end{tabular}

fection. SARS-CoV-2 transmission is not limited to respiratory tracts. Some studies have shown SARSCoV-2 to spread through aerosol. SARS-CoV-2 is a direct threat to one's health and life $[11,45,46]$.

\section{INFECTION PROPHYLAXIS}

The knowledge of the mechanisms in which biological factors affect the human body enables the undertaking of effective measures of preventing contagious diseases from spreading among paramedics.

Regardless of existing legal regulations [2], an important element of prophylaxis is the education and supplying of personal protection equipment (PPE), as well as compulsory and recommended preventative vaccines recognized in legal regulations [47-49], which are an important aspect of prophylactic healthcare of the workers. Strengthening the awareness of possible threats among medical workers should encourage the development of behaviors enabling the minimalization of health risks. Widespread use of PPE is able to protect an employee from potential harm coming from biological factors.

Proper protection against biological factors in the work of a paramedic should primarily rely on complying with the commonly existing and adopted epidemiological-sanitary rules, and a well-carried out the evaluation of occupational risk, including the possible work conditions that might come about and its inherent dangers like exposure to harmful biological pathogens while carrying out specific work tasks [1, 3]. Possible examples of harmful biological pathogen factors with are a hazard in the work environment of a paramedic are summarized in Table 5 [50].

\section{CONCLUSIONS}

1. Research into the effects of biological factors on the health of paramedics is incomplete.

2. Further research aiming to fully understand the effect spectrum of biological factors on the incidence of contagious diseases in this professional group is required.

3. Estimating the scale of the phenomenon and decreasing the number of occupational exposure incidences amongst paramedics should be a priority as far as epidemiological safety is concerned.

4. Training that aims to increase awareness in the area of existing procedures, including the use of PPEs and the obligation to register injuries suffered from sharp objects, plays a significant role in prophylaxis.

5. Prophylactic measures need to be implemented on a multidimensional scale, and their effectiveness should be ensured through constant monitoring and supervision on each level of evaluating working conditions. 


\section{Conflict of interest}

the authors declare no potential conflict of interest with respect to the authorship and/or publication of this article.

\section{REFERENCES}

1. Chmielewski J, Dziechciaż M, Czarny-Działak M, et al. Environmental health threats in the work process [in Polish]. Environ Med. 2017; 20(2): 52-61, doi: 10.19243/2017207.

2. Rozporządzenie Ministra Zdrowia z dnia 22 kwietnia 2005 r. w sprawie szkodliwych czynników biologicznych dla zdrowia w środowisku pracy oraz ochrony zdrowia pracowników zawodowo narażonych na te czynniki/Ordinance of the Minister of Health of 22 April 2005 on biological agents harmful to health in the workplace and health protection of workers occupationally exposed to such agents (Dz. U. nr 81 poz. 716, z późn. zm.). https://isap.sejm.gov.pl/isap.nsf/download. xsp/WDU20050810716/0/D20050716.pdf (2021-11-08).

3. Chmielewski J, Galińska EM, Nagas T. Environmental biological hazards in veterinary practic [in Polish]. Życie Weterynaryjne. 2015; 90(6): 353-357.

4. Leineweber C, Marklund S, Gustafsson K, et al. Work environment risk factors for the duration of all cause and diagnose-specific sickness absence among healthcare workers in Sweden: a prospective study. Occup Environ Med. 2020; 77(11): 782-789, doi: 10.1136/ oemed-2020-106510, indexed in Pubmed: 32764106.

5. Sagha Zadeh R, Shepley MM, Owora AH, et al. The importance of specific workplace environment characteristics for maximum health and performance: healthcare workers' perspective. J Occup Environ Med. 2018; 60(5): e245-e252, doi: 10.1097/J0M.0000000000001248, indexed in Pubmed: 29227360.

6. Ornell F, Halpern SC, Kessler FH, et al. The impact of the COVID-19 pandemic on the mental health of healthcare professionals. Cad Saude Publica. 2020; 36(4): e00063520, doi: 10.1590/0102-311X00063520, indexed in Pubmed: 32374807.

7. Chmielewski J, Nowak-Starz G, Rutkowski A, et al. Occupational exposure to carcinogens and mutagens in the work environment [in Polish]. Przem Chem. 2020; 99(3): 397-405, doi: 10.15199/62.2020.3.8.

8. Chmielewski J, Galińska EM, Anusz K, et al. Personal protection measures in veterinary practice [in Polish]. Życie Weterynaryjne. 2015; 90(5): 277-280.

9. Ganczak M, Topczewska K, Biesiada D, et al. Frequency of occupational bloodborne infections and sharps injuries among polish paramedics from selected ambulance stations. Int J Environ Res Public Health. 2020; 18(1): 60, doi: 10.3390/ijerph18010060, indexed in Pubmed: 33374768 .

10. Nguyen J, Liu A, McKenney M, et al. Impacts and challenges of the COVID-19 pandemic on emergency medicine physicians in the United States. Am J Emerg Med. 2021; 48: 38-47, doi: 10.1016/j. ajem.2021.03.088, indexed in Pubmed: 33836387.

11. Chmielewski J, Raczek M, Puścion M, et al. COVID-19 caused by the SARS-CoV-2 virus as an occupational disease of medical professionals [in Polish]. Med Og Nauk Zdr. 2021; 27(3): 235-243, doi: 10.26444/ monz/139319.

12. Ornell F, Halpern SC, Kessler FH, et al. The impact of the COVID-19 pandemic on the mental health of healthcare professionals. Cad Saude Publica. 2020; 36(4): e00063520, doi: 10.1590/0102-311X00063520, indexed in Pubmed: 32374807.

13. Główny Urząd Statystyczny. Warunki pracy w 2020 r./Central Statistical Office. Working conditions in 2020. https://stat.gov.pl/obszary-tematyczne/rynek-pracy/warunki-pracy-wypadki-przy-pracy/warunkipracy-w-2020-roku,1,15.html (2021-11-08).

14. Narodowy Instytut Zdrowia Publicznego PZH - Państwowy Instytut Badawczy. Meldunki epidemiologiczne EPIMELD/National Institute of Public Health PZH - National Research Institute. EPIMELD epidemiological medlocations. http://wwwold.pzh.gov.pl/oldpage/epimeld/ index_p.html (2021-11-08).

15. Główny Inspektorat Sanitarny. Stan Sanitarny Kraju w 2020 r./Chief Sanitary Inspectorate. The Sanitary Status of the Country in 2020. https://www.gov.pl/web/gis/stan-sanitarny-kraju-w-2020-roku (2021-11-08).

16. Państwowa Inspekcja Pracy. Sprawozdanie z działalności Państwowej Inspekcji Pracy w 2020 r./State Labour Inspectorate. Report on the activities of the State Labour Inspectorate in 2020. https://www.pip.gov.pl/ $\mathrm{pl} / \mathrm{f} / \mathrm{v} / 242408 / \mathrm{Sprawozdanie} \% 202020 . p d f \#$ page $=102$ (2021-11-08).

17. Najwyższa Izba Kontroli Delegatura w Katowicach. Wystąpienie pokontrolne LKA.411.001.07.2020 Krakowskie Pogotowie Ratunkowe w Krakowie/Supreme Chamber of Control Katowice Branch. Post-audit report LKA.411.001.07.2020 Krakow Ambulance Service in Krakow. https://www.nik.gov.pl/kontrole/R/20/001/LKA/ (2021-11-08).

18. Najwyższa Izba Kontroli. Informacja o wynikach kontroli LWA.430.005.2020 Funkcjonowanie Systemu Ratownictwa Medycznego/Supreme Audit Office. Information on the results of the audit LWA.430.005.2020 Functioning of the Medical Rescue System. https:// www.nik.gov.pl/plik/id,23528,vp,26262.pdf (2021-11-08).

19. Centrum e-Zdrowia. Biuletyn Statystyczny 2020/Center for eHealth. Statistical Bulletin 2020. https://cez.gov.pl/fileadmin/user_upload/ Biuletyny_informacyjny/biuletyn_statystyczny_2020_5fa959206ef00. pdf (2021-11-08).

20. Daugherty EL, Carlson AL, Perl TM. Planning for the inevitable: preparing for epidemic and pandemic respiratory illness in the shadow of H1N1 influenza. Clin Infect Dis. 2010; 50(8): 1145-1154, doi: 10.1086/651272, indexed in Pubmed: 20225936.

21. Bentley MA, Levine R. A national assessment of the health and safety of emergency medical services professionals. Prehosp Disaster Med. 2016; 31(S1): S96-S104, doi: 10.1017/S1049023X16001102, indexed in Pubmed: 27890031.

22. Dowlati M, Seyedin H, Moslehi S. Hospital preparedness measures for biological hazards: a systematic review and meta-synthesis. Disaster Med Public Health Prep. 2020 [Epub ahead of print]: 1-14, doi: 10.1017/dmp.2020.132, indexed in Pubmed: 32713417.

23. Sacadura-Leite E, Mendonça-Galaio L, Shapovalova 0, et al. Biological hazards for healthcare workers: occupational exposure to vancomy- 
cin-resistant staphylococcus aureus as an example of a new challenge. Port J Public Health. 2018; 36(1): 26-31, doi: 10.1159/000487746.

24. Lewandowicz-Uszyńska A, Naporowski P, Pasternak G, et al. Identification of etiological agents of selected bacterial and viral infections based on serological tests. Postepy Hig Med Dosw. 2018; 72: 1162-1178, doi: 10.5604/01.3001.0012.8266.

25. Boal WL, Leiss JK, Ratcliffe JM, et al. Blood exposure among paramedics: incidence rates from the national study to prevent blood exposure in paramedics. Ann Epidemiol. 2006; 16(9): 720-725, doi: 10.1016/j. annepidem.2005.12.007, indexed in Pubmed: 16581265.

26. Luksamijarulkul P, Pipitsangjan S, Vatanasomboon P. Occupational risk towards blood-borne infections among ambulance personnel in a provincial hospital network in Thailand. Southeast Asian J Trop Med Public Health. Southeast Asian J Trop Med Public Health. 20154; 45(4): 940-948.

27. Szarpak $\measuredangle$. Knowledge of aseptics and antisepsis and following their rules as elements of infection prevention in the work of paramedics [in Polish]. Med Pr. 2013; 64(2): 239-243, doi: 10.13075/ mp.5893/2013/0020.

28. Garus-Pakowska A, Górajski M, Szatko F. Awareness of the risk of exposure to infectious material and the behaviors of Polish paramedics with respect to the hazards from blood-borne pathogens-a nationwide study. Int J Environ Res Public Health. 2017; 14(8): 843, doi: 10.3390/ ijerph14080843, indexed in Pubmed: 28749410.

29. Butsashvili M, Kamkamidze G, Kajaia M, et al. Occupational exposure to body fluids among health care workers in Georgia. Occup Med (Lond). 2012; 62(8): 620-626, doi: 10.1093/occmed/kqs121, indexed in Pubmed: 22869786.

30. Coppola N, De Pascalis S, Onorato L, et al. Hepatitis B virus and hepatitis C virus infection in healthcare workers. World J Hepatol. 2016; 8(5): 273-281, doi: 10.4254/wjh.v8.i5.273, indexed in Pubmed: 26925201.

31. Jacob ST, Crozier I, Fischer WA, et al. Viral Hemorrhagic Fever Consortium. Priorities for Ebola virus disease response in west Africa. Lancet. 2014; 384(9957): 1843, doi: 10.1016/50140-6736(14)61609-3, indexed in Pubmed: 25262343.

32. Lee JH, Cho J, Kim YJ, et al. Occupational blood exposures in health care workers: incidence, characteristics, and transmission of bloodborne pathogens in South Korea. BMC Public Health. 2017; 17(1): 827, doi: 10.1186/s12889-017-4844-0, indexed in Pubmed: 29047340.

33. Nemr N, Kishk R, Mandour M, et al. Occupational risk of hepatitis $B$ virus exposure: overview and recommendations. Suez Canal University Medical Journal. 2018; 21(2): 59-70, doi: 10.21608/ scumj.2018.42461.

34. Garus-Pakowska A, Górajski M. Behaviors and attitudes of Polish health care workers with respect to the hazards from blood-borne pathogens: a questionnaire-based study. Int J Environ Res Public Health. 2019; 16(5): 891, doi: 10.3390/ijerph16050891, indexed in Pubmed: 30870976.

35. Fedorczuk W, Pawlas K. Occupational risk factors of a medical rescue worker [in Polish]. Hygeia Public Health. 2011; 46(4): 437-441.
36. Parekh B, Ou CY, Fonjungo $P$, et al. Diagnosis of human immunodeficiency virus infection. Clin Microbiol Rev. 2018; 32(1): e00064-18, doi: 10.1128/cmr.00064-18, indexed in Pubmed: 30487166.

37. Yazie TD, Sharew GB, Abebe W. Knowledge, attitude, and practice of healthcare professionals regarding infection prevention at Gondar University referral hospital, northwest Ethiopia: a cross-sectional study. BMC Res Notes. 2019; 12(1): 563, doi: 10.1186/s13104-019-4605-5, indexed in Pubmed: 31500659.

38. Trzcińska A. Occupational exposure - the problem still valid [in Polish]. Renal Disease and Transplantation Forum. 2016; 9(1): 66-71.

39. Gańczak M, Topczewska K. Risk of occupational exposure to bloodborne pathogens in paramedics [in Polish]. Med Pr. 2018; 69(6): 685694, doi: 10.13075/mp.5893.00741, indexed in Pubmed: 30245520.

40. Polskie Towarzystwo Pielęgniarek Anestezjologicznych i Intensywnej Opieki. Implementacja Dyrektywy Rady 2010/32/UE/w polskich szpitalach. Raport z badania/Polish Society of Anaesthesiological and Intensive Care Nurses. Implementation of Council Directive 2010/32/ EU in Polish hospitals. Report from the survey, Warszawa, 2019. https://pspe.pl/wp-content/uploads/2019/04/RAPORT-BADA\%C5\%830-ZAK\%C5\%81UCIACH_PTPAil0.pdf (2021-11-08).

41. Ebisz M, Król K, Lar K, et al. The health risk due to exposure to bioaerosol occurring in health care institutions [in Polish]. Med Srod. 2016; 19(2): 55-62.

42. Koch A, Mizrahi V. Mycobacterium tuberculosis. Trends Microbiol. 2018; 26(6): 555-556, doi: 10.1016/j.tim.2018.02.012, indexed in Pubmed: 29580884.

43. Vaz LE. Meningococcal Disease. Pediatr Rev. 2017; 38(4): 158-169, doi: 10.1542/pir.2016-0131, indexed in Pubmed: 28364047.

44. de Wit E, van Doremalen N, Falzarano D, et al. SARS and MERS: recent insights into emerging coronaviruses. Nat Rev Microbiol. 2016; 14(8): 523-534, doi: 10.1038/nrmicro.2016.81, indexed in Pubmed: 27344959.

45. Kirtipal N, Bharadwaj S, Kang SGu. From SARS to SARS-CoV-2, insights on structure, pathogenicity and immunity aspects of pandemic human coronaviruses. Infect Genet Evol. 2020; 85: 104502, doi: 10.1016/j. meegid.2020.104502, indexed in Pubmed: 32798769.

46. Wang MY, Zhao R, Gao L, et al. SARS-CoV-2: structure, biology, and structure-based therapeutics development. Front Cell Infect Microbiol. 2020; 10: 587269, doi: 10.3389/fcimb.2020.587269, indexed in Pubmed: 33324574.

47. Ustawa z dnia 5 grudnia 2008 r. o zapobieganiu oraz zwalczaniu zakażeń i chorób zakaźnych u ludzi/Act of December 5, 2008 on prevention and control of infections and infectious diseases in humans (tekst jedn. Dz.U. z 2017 poz. 151). https://isap.sejm.gov.pl/isap.nsf/ DocDetails.xsp?id=WDU20082341570 (2021-11-08).

48. Rozporządzenie Ministra Zdrowia z dnia 18 sierpnia 2011 r. w sprawie obowiązkowych szczepień ochronnych/Ordinance of the Minister of Health of 18 August 2011 on mandatory preventive vaccinations (tekst jedn. Dz.U. z 2018 poz. 753). https://isap.sejm.gov.pl/isap.nsf/ DocDetails.xsp?id=WDU20111821086 (2021-11-08). 
49. Rozporządzenie Rady Ministrów z dnia 3 stycznia 2012 r. w sprawie wykazu rodzajów czynności zawodowych oraz zalecanych szczepień ochronnych wymaganych u pracowników, funkcjonariuszy, żołnierzy lub podwładnych podejmujących pracę, zatrudnionych lub wyznaczonych do wykonywania tych czynności/Ordinance of the Council of Ministers of 3 January 2012 on the list of types of professional activities and recommended preventive vaccinations required for employees, officers, soldiers or subordinates undertaking work, em- ployed or appointed to perform such activities (Dz.U. z 2012 poz.40). https://isap.sejm.gov.pl/isap.nsf/download.xsp/WDU20120000040/0/ D20120040.pdf (2021-11-08).

50. Dutkiewicz J, Śpiewak R, Jabłoński L, Szymańska J. Biologiczne czynniki zagrożenia zawodowego. Klasyfikacja, narażone grupy zawodowe, pomiary, profilaktyka/Biological occupational hazard factors. Classification, exposed occupational groups, measurement, prevention. [in Polish]. Ad Punctum, Lublin 2007. 